(C) Rakhmatulina A.A., Luneva S.N., Nakoskina N.V., Kliushin N.M., Lyulin S.V., Dolganova T.I., Menshchikova T.I., Leonchuk D.S., 2021

DOI 10.18019/1028-4427-2021-27-3-325-330

\title{
The serum vascular endothelial growth factor levels in patients with high-energy trauma complicated with infection
}

\author{
A.A. Rakhmatulina ${ }^{1}$, S.N. Luneva ${ }^{1}$, N.V. Nakoskina ${ }^{1}$, N.M. Kliushin ${ }^{1}$, S.V. Lyulin ${ }^{2,3}$, T.I. Dolganova ${ }^{1}$, \\ T.I. Menshchikova ${ }^{1}$, D.S. Leonchuk ${ }^{1}$
}

\author{
${ }^{1}$ Ilizarov National Medical Research Centre for Traumatology and Orthopedics, Kurgan, Russian Federation \\ ${ }^{2}$ Ural State Medical University, Ekaterinburg, Russian Federation \\ ${ }^{3}$ Central City Clinical Hospital № 23, Ekaterinburg, Russian Federation
}

\begin{abstract}
Introduction There is a lack of studies analyzing the molecular aspects of body functioning in purulent complications of bone tissue. The purpose of the review was to explore the serum vascular endothelial growth factor (VEGF) levels in patients with high-energy trauma complicated with infection. Material and methods The study included 36 individuals who sustained a high-energy injury. The participants were identified as no-infection patients (Group I) and those who developed infection during treatment (Group II). Enzyme immunoassay was employed to quantify VEGF with Thermofisher immunoassay analyzer (USA). The study was performed according to the methodology from the R \& D Systems kit manual (Angiopoietin-1 and -2 (Ang-1, Ang-2)), platelet-derived growth factors (PDGF-AB, PDGF$\mathrm{BB})$, Invitrogen (epidermal growth factor (EGF), vascular endothelial growth factor (VEGF), RayBiotech (macrophage stimulating protein (MSP), Biomerika Inc. (Calcitonin-calciotonin) USA) and Immunodiagnostic (bone sialoprotein (BSP) (Germany). HITACHI HI Vision Avius ultrasound scanner was used to explore vessels of the soft tissues and the periosteum at the site of regeneration (defect). Results There were no differences in the serum growth factor levels among the participants by gender. Patients of Group II showed $60 \%$ reduction in the Ang- 2 and VEGF concentration as compared with that in the no-infection group. The serum EGF concentration was 1.6 times higher in individuals suffering from complications of high-energy trauma than in no-infection patients. There were no significant differences in plateletderived growth factor PDGF-AB, PDGF-BB between the groups. Changes in the VEGF concentration were confirmed by the results of Doppler ultrasonography. Conclusion The findings suggest that the VEGFs examined can be additional diagnostic and prognostic markers for the cohort of patients.
\end{abstract}

Keywords: high-energy trauma, growth factors, connective tissue, osteomyelitis

\section{INTRODUCTION}

The Ilizarov external fixation has been widely used in orthopaedic practice and in the treatment of severe injuries, posttraumatic conditions and complications, in particular [1]. There is a lack of studies analyzing the molecular aspects of body functioning in osteomyelitis. There are several publications describing the role of growth factors in osteosynthesis. Bone regeneration is reported to be accompanied by increased concentration of angiogenic growth factors in the blood serum [2]. Ang-1, Ang-2, and EGF are involved in reparative bone regeneration [3]. Chronic osteomyelitis is known to be associated with severe vascular disorders of the segment [4, 5], and primary disorders of vascularization are often one of the causes of acute and chronic bone infection [6]. Vascular endothelial growth factors (VEGF) are primarily involved in bone regeneration and the transformation of cartilage into bone (endochondral ossification) during distractional regeneration [7]. There is no data in the literature regarding the concentration, dynamics in the level of VEGF during the orthopaedic treatment of severe high-energy injuries and their impact on chronic purulent infection after surgical management with the Ilizarov external fixation, in particular. There are no papers to show the spectrum of growth factors produced during distractional bone fixation, as there are no publications reporting the comparative analysis of changes in growth factors developing with a musculoskeletal pathology.

The purpose of the review was to explore the serum VEGF levels in patients with high-energy trauma complicated with infection.

@ Rakhmatulina A.A., Luneva S.N., Nakoskina N.V., Kliushin N.M., Lyulin S.V., Dolganova T.I., Menshchikova T.I., Leonchuk D.S. The serum vascular endothelial growth factor levels in patients with high-energy trauma complicated with infection. Genij Ortopedii, 2021, vol. 27, no 3, pp. 325-330. DOI 10.18019/1028-4427-2021-27-3-325-330 


\section{MATERIAL AND METHODS}

The paper presents a review of changes in the serum VEGF levels in patients with musculoskeletal injuries complicated by the purulent inflammation. The study included 36 individuals who sustained a high-energy injury. All the patients were treated at the level 1 trauma center. Patients with purulent infection were transferred to inpatient treatment in the departments of the Clinic of Osteology Infection, the Federal State Budgetary Institution "Russian Ilizarov Scientific Center for Restorative Traumatology and Orthopaedics (FSBI 'RISC RTO'). Patients were assigned to 2 groups. The participants were identified as no-infection patients (Group I) and those who developed infection during treatment (Group II). The patients' age ranged from 18 to 60 years. All the participants were persons of working age. The tests were performed on the 3rd postoperative day for prediction of infection. Blood serum parameters of the patients were compared with those of 20 subjectively healthy controls aged 20 to 45 years. Group I consisted of 25 individuals including 16 (64\%) male and 9 (36\%) patients. Group II comprised 11 individuals including 7 (64\%) male and 4 (36\%) female patients.

Enzyme immunoassay was employed to quantify VEGF with Thermofisher immunoassay analyzer (USA). The study was performed according to the methodology from the R \& D Systems kit manual (Angiopoietin-1 and -2 (Ang-1, Ang-2), platelet-derived growth factors (PDGF-AB, PDGF$\mathrm{BB}$ ), Invitrogen (epidermal growth factor (EGF), vascular endothelial growth factor (VEGF), RayBiotech (macrophage stimulating protein (MSP), Biomerika Inc. (Calcitonin-calciotonin) USA) and Immunodiagnostic (bone sialoprotein (BSP), (Germany). HITACHI HI Vision Avius ultrasound scanner was used to explore vessels of the soft tissues and the periosteum at the site of regeneration (defect). Multiple frequency $5 \backslash 12 \mathrm{Mhz}$ ultrasound linear probe was used in the B-mode for color and energy Doppler mapping and spectral Doppler of blood flow. Blood microcirculation was evaluated with laser Doppler flowmetry (LDF) using the BLF21 Laser Doppler Flowmeter (Transonic Systems Inc., USA). Occlusion test was used for local ischemic conditioning with the cuff placed on tibia.

With measurements of capillary blood flow at rest (CBFrest, BPU) and after 3-minute ischemia (CBFpeak, BPU), the calculations made included the peak blood flow index was calculated (PBFI, $\%=$ CBFpeak/CBFrest $\times 100 \%$ ) as the increase in capillary blood flow after the 3-minute occlusion; $\Delta \mathrm{t}$, sec., the time interval between the removal of the occlusion and the maximum increase in capillary blood flow; the half - recovery period of the capillary blood flow (T1/2, sec.) and duration of reactive hyperemia ( $\mathrm{T}$, sec.), the time interval between the maximum increase in capillary blood flow and the initial parameters restituted.

The study received a favourable opinion from the relevant research ethics committee of the Russian Ilizarov Scientific Center for Restorative Traumatology and Orthopaedics Ministry of Health of the Russian Federation. The study was performed in accordance with ethical principles for medical research involving human subjects stated in the Declaration of Helsinki developed by the World Medical Association as revised in 2000, Order of the Ministry of Health of the RF dtd 19th June 2003 No. 266 on Clinical Practice Guidelines in the Russian Federation.

Measures of variation used for small samples were employed for statistical analysis with the level of statistical significance quoted as $p \leq 0.05$. The statistical significance of the differences between the two unrelated samples was identified with the Wilcoxon signed-rank test, the Mann-Whitney test, and the Dunn test [8]. Microsoft Office Excel and Atte Stat integrated module version 1.0 developed by I.P. Gaidyshev, information and computing department FSBI 'RISC RTO' were used to complete data analysis reports [9]. Data were presented as medians, lower and upper quartiles.

\section{RESULTS}

There were no differences in the serum growth factor levels among the participants by gender.
There were no significant differences in the serum Ang-1 levels in patients who sustained high-energy 
injury (Fig. 1) with $7 \%$ difference between the groups. Patients of Group II showed 60\% reduction in the Ang-2 and VEGF levels as compared with that in the no-infection group, $p=0.034$. The serum EGF concentration was 1.6 times higher in individuals suffering from complications of high-energy trauma than in no-infection patients. There were no significant differences in platelet-derived growth factor PDGF-AB, PDGF-BB between the groups (Fig. 2). There were no significant differences in concentrations of calciotonin, bone sialoprotein and macrophage-stimulating protein between the groups.
Changes in the VEGF levels were confirmed by the results of Doppler ultrasonography (Fig. 3) that showed an increase in the color cartogram of the arterial and venous components seen in the cortical bone of the defect and the adjacent soft tissues in no-infection patients with high-energy trauma. Patients who developed infection during treatment demonstrated poor vascular network in the cortical bone and the adjacent soft tissues.

The microcirculation of dermal tissues (Table 1) was evaluated with laser Doppler flowmetry.

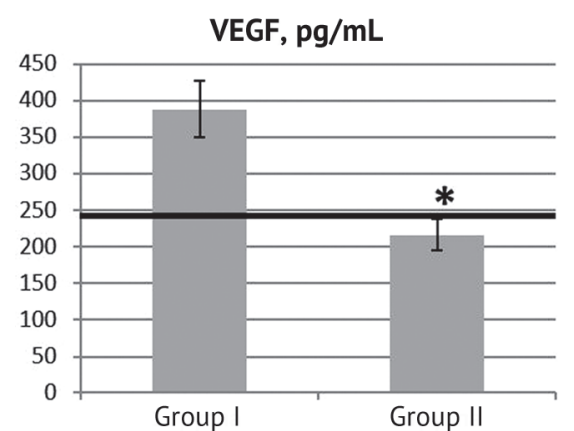

EGF, pg/mL

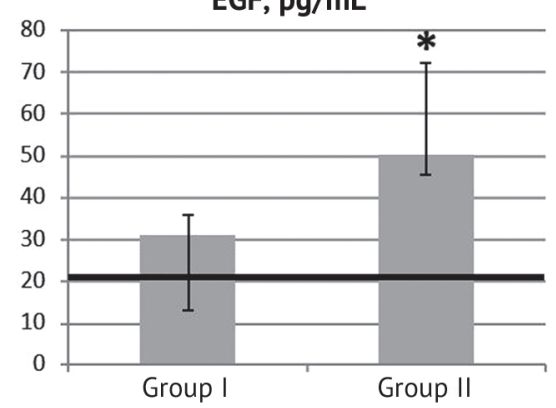

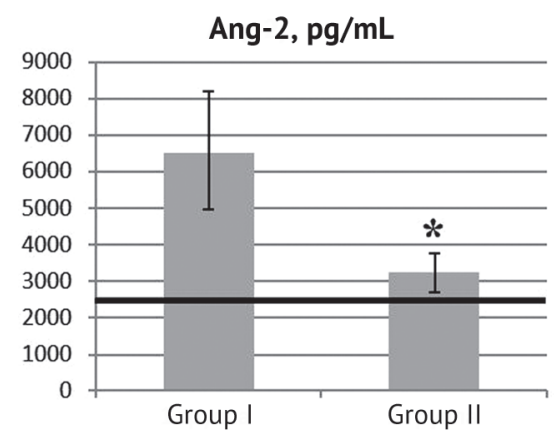

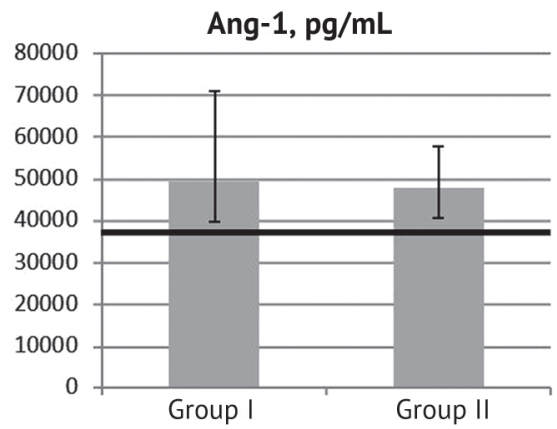

Fig. 1 Dynamics in measurements of serum vascular growth factors in patients with high-energy trauma during treatment with Ilizarov external fixation. Note: Ang-1, Ang-2 (Angiopoietin -1 and -2), EGF (epidermal growth factor), VEGF (vascular endothelial growth factor); the horizontal bar shows the median of the controls; * statistically significant difference between the groups, $\mathrm{p} \leq 0.05$

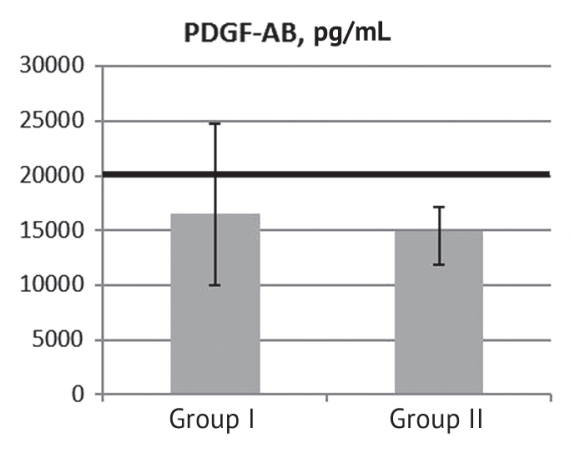

BSP, $\mathrm{ng} / \mathrm{mL}$

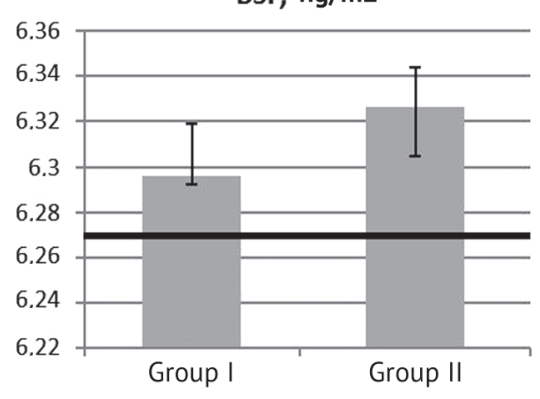

PDGF-BB, pg/mL

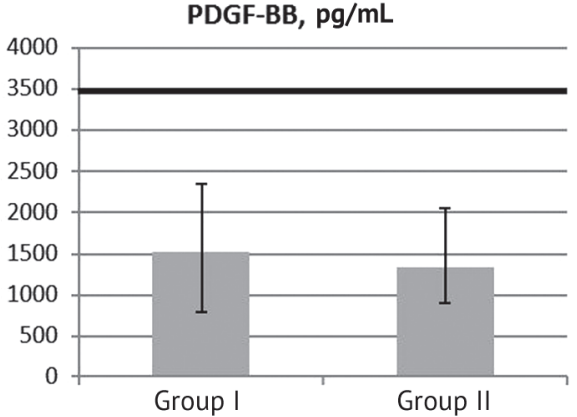

Calcitonin, pg/mL

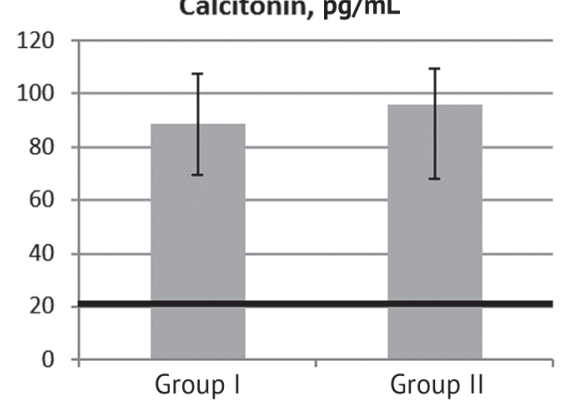

MSP, $\mathrm{pg} / \mathrm{mL}$

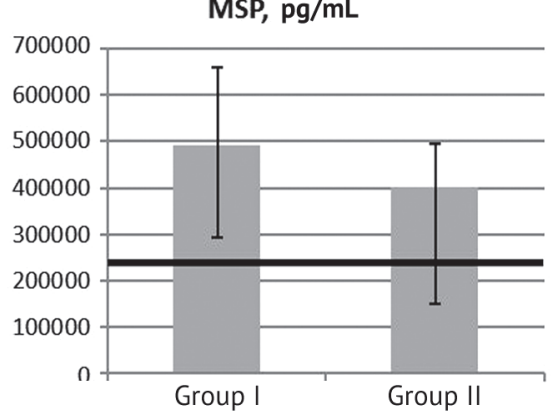

Fig. 2 Dynamics in measurements of serum regulatory factors in patients with high-energy trauma during treatment with Ilizarov external fixation. Note: PDGF-AB, PDGF-BB (platelet-derived growth factors), MSP (macrophage stimulating protein), BSP (bone sialoprotein), Calcitonin; the horizontal bar shows the median of the controls; *statistically significant difference between the groups, $\mathrm{p} \leq 0.05$ 


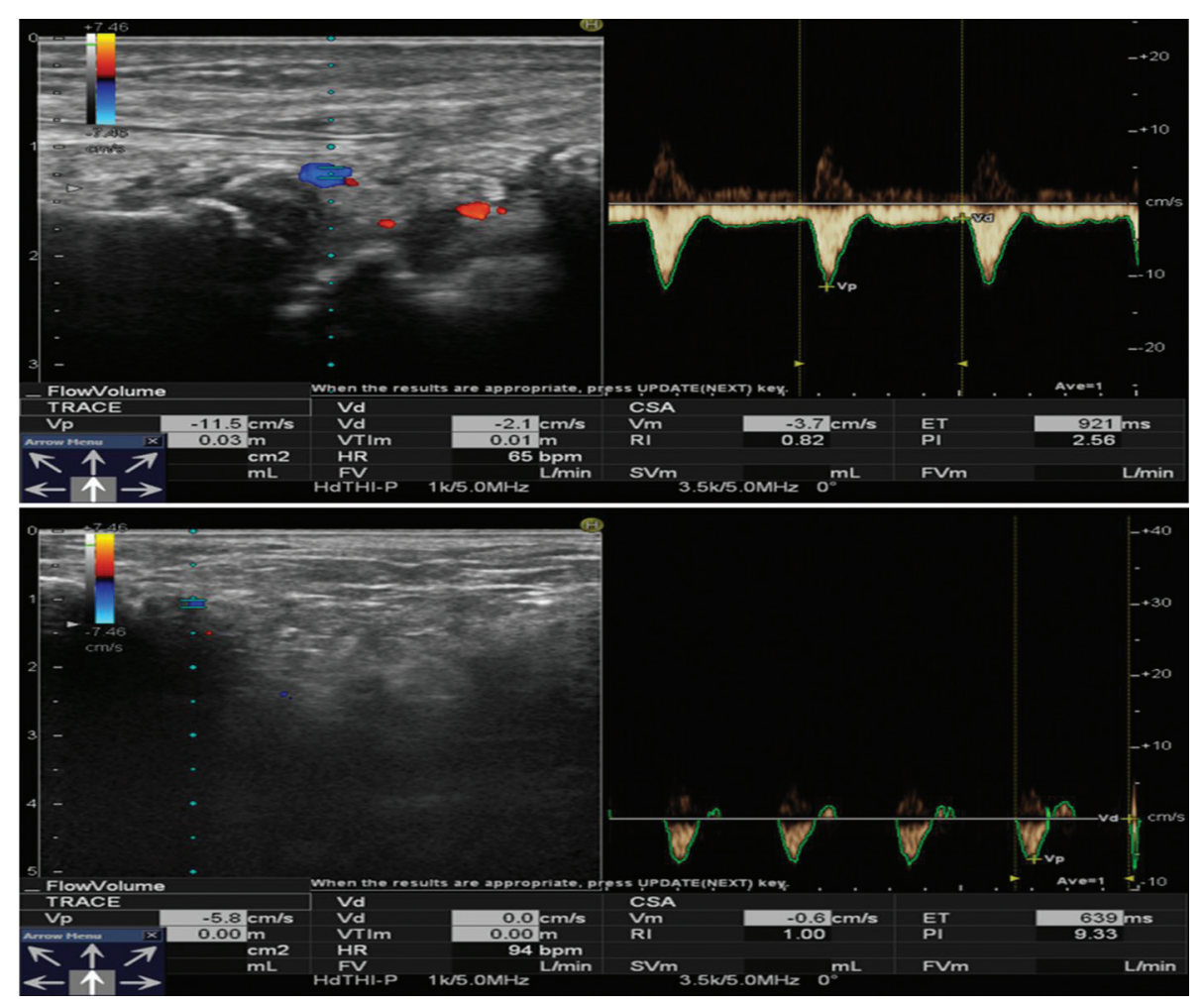

Patient $\mathrm{T}$.

(a no-infection case) Scanning along the long axis of the segment showed enhanced vascular network at the defect site

Patient K.

(an infection case)

Scanning along the long

axis of the segment

showed a singular vessel at

the defect site

Fig. 3 Color cartogram and Doppler ultrasonography of arterioles in the cortical bone and the adjacent soft tissues

Table 1

Microcirculation of dermal tissues measured in patients with high-energy trauma during treatment with Ilizarov external fixation

\begin{tabular}{|c|c|c|}
\hline Description & Group I & Group II \\
\hline KK rest & $1.8(1.5 \div 2.1)$ & $2.0(1.8 \div 2.9)$ \\
\hline KK peak & $9.4(6.4 \div 11.3)$ & $3.0(4.5 \div 93)$ \\
\hline PBFI, \% & $575(410 \div 625)$ & $10(5 \div 12)^{*}$ \\
\hline$\otimes$ t, sec. & $20(15 \div 35)$ & $25(20 \div 35)$ \\
\hline T1/2, sec. & $35(25 \div 40)$ & $60(40 \div 75)^{*}$ \\
\hline T, sec. & $120(90 \div 300)$ & $\%$ \\
\hline
\end{tabular}

Note: CBFrest BPU, capillary blood flow at rest; CBFpeak, BPU, capillary blood flow after 3-minute ischemia; PBFI, \% index of peak blood flow; $\otimes \mathrm{t}$, sec., the time interval between the removal of the occlusion and the maximum increase in capillary blood flow; T1/2, sec., the half - recovery period of the capillary blood flow; T, sec., duration of reactive hyperemia; *statistically significant difference between the groups, $\mathrm{p} \leq 0.05$.

There were no significant differences in CBFrest and CBFpeak indicating to retained capacity of the vascular bed but 3-minute ischemia test revealed vasoconstriction in Group II with reduced vascularity, metabolic disorders and vascular endothelial dysfunction with sharp reduction in the peak blood flow index, in the time interval from the removal of occlusion to the appearance of the maximum increase in capillary blood flow and in the duration of reactive hyperemia that was interpreted as the sign of vasoconstriction [10].

\section{DISCUSSION}

Purulent inflammation is one of the most devastating complications of high-energy trauma that are dependent on the severity of the injury, the volume of surgical intervention and the availability of preventive measures [11]. And there is a question: why an adverse event tends to develop in a specific case if all else were equal including the extent of medical care rendered? The patient's health status, the immune response, comorbidities and infection resistance can be associated with higher risk of infection $[12,13]$. There is little data overall regarding predictors and mechanisms for the occurrence of infections [14]. Maintaining a normal level of blood flow is essential for the repair of structural and functional injury to 
cells in high-energy injuries accompanied by hypoxia and tissue ischemia [15].

VEGF is known as a heterodimeric glycoprotein growth factorwhichisresponsible forrevascularization and angiogenesis [16]. In addition to that, VEGF is able to increase vascular permeability as a mitogen for vascular epithelial cells [17]. The combined effect of VEGF and Ang-1 in blood serum has been shown to contribute to increased tissue vascularization and indicate the presence of persistent inflammation, which is a precursor to morphological changes that would lead to the progression of connective tissue degeneration [17]. Our findings suggest that Ang2 and VEGF can act synergistically in patients who develop infection postoperatively. A decreased level of growth factors can lead to greater vascular permeability for the pathogens, the increased number of pyogenic microorganisms that would cause changes in metabolism at the site of involvement and other organs and tissues with resultant changes in the functioning of life support systems secondary to the general destruction of the vessels of the affected segment [18].

EGF as the epidermal growth factor stimulating cell growth promotes the epithelial regulation and differentiation and the formation of new vessels [19]. An increased EGF level was detected in the peripheral blood of patients with purulent infection and assumed as compensatory to the poor vascularity in the cortical bone and adjacent soft tissues. There were no statistically significant differences in the levels of platelet growth factors (PDGF-AB, PDGF-BB), Calcitonin, BSP and macrophage-stimulating protein.

\section{CONCLUSION}

The findings registered in the patients of our series indicate to a moderate extent of recovered vascularity and blood flow at the site of involvement. An imbalance of angiogenic growth factors in the blood serum was revealed in patients with chronic posttraumatic osteomyelitis. The available data suggest that the growth factors under study may be additional diagnostic and prognostic markers of purulent inflammatory complications of high-energy trauma.

Conflict of interest statement. None of the authors has any potential conflict of interest.

\section{REFERENCES}

1. Lapynin A.I., Popova L.A., Kovinka M.A., Luneva S.N., Tushina N.V. Diagnosticheskoe znachenie pokazatelei gomeostaza bolnykh v otdalennye sroki reabilitatsii ikh metodom upravliaemogo chreskostnogo osteosinteza po povodu osteomieliticheskikh polostei kostei nizhnikh konechnostei [Diagnostic value of homeostasis values of patients in the long-term periods of the rehabilitation by the method of controlled transosseous osteosynthesis for osteomyelitic cavities of the lower limb bones]. Tekhnologii Zhivykh Sistem, 2014, vol. 11, no. 5, pp. 54-58. (in Russian)

2. Hankenson K.D., Dishowitz M., Gray C., Schenker M. Angiogenesis in bone regeneration. Injury, 2015, vol. 42, no. 6, pp. 556-561. DOI: 10.1016/j.injury.2011.03.035

3. Caplan A.I., Correa D. PDGF in bone formation and regeneration: new insights into a novel mechanism involving MSCs. J. Orthop. Res., 2011, vol. 29, no. 12, pp. 1795-1803. DOI: 10.1002/jor.21462

4. Wahl E.C., Aronson J., Liu L., Skinner R.A., Miller M.J., Cockrell G.E., Fowlkes J.L., Thrailkill K.M., Bunn R.C., Ronis M.J., Lumpkin C.K. Jr. Direct bone formation during distraction osteogenesis does not require TNFalpha receptors and elevated serum TNFalpha fails to inhibit bone formation in TNFR1 deficient mice. Bone, 2010, vol. 46, no. 2, pp. 410-417. DOI: 10.1016/j. bone.2009.09.011

5. Rosano A., Botto L.D., Botting B., Mastroiacovo P. Infant mortality and congenital anomalies from 1950 to 1994: an international perspective. J. Epidemiol. Community Health, 2000, vol. 54, no. 9, pp. 660-666. DOI: 10.1136/jech.54.9.660

6. Fawcett L.B., Buck S.J., Brent R.L. Limb reduction defects in the A/J mouse strain associated with maternal blood loss. Teratology, 1998, vol. 58, no. 5, pp. 183-189. DOI: 10.1002/(SICI)1096-9926(199811)58:5<183::AID-TERA4>3.0.CO;2-L

7. Stogov M.V., Luneva S.N., Novikov K.I. Growth factors in human serum during operative tibial lengthening with the Ilizarov method. J. Orthop. Res., 2013, vol. 31, no. 12, pp. 1966-1970. DOI 10.1002/jor.22454

8. Glants S. Mediko-biologicheskaia Statistika [Medical-and-Biological Statistics]. M., Praktika, 1999, 459 p. (in Russian)

9. Gaidyshev I.P. Reshenie nauchnykh i inzhenernykh zadach sredstvami Excel, VBA i $C / C++$ [Solution of scientific and engineering problems by means of Excel, VBA and C/C++]. SPb., BKhV-Petersburg, 2004, 512 p. (in Russian)

10.Fedorovich A.A. Neinvazivnaia otsenka vazomotornoi i metabolicheskoi funktsii mikrososudistogo endoteliia v kozhe cheloveka [Non-invasive assessment of vasomotor and metabolic function of microvascular endothelium in human skin]. Regionarnoe Krovoobrashchenie i Mikrotsirkuliatsiia, 2013, vol. 12, no. 2, pp. 15-25. (in Russian)

11. Miromanov A.M., Miromanova N.A., Namokonov E.V. Prognozirovanie gnoino-vospalitelnykh oslozhnenii v rannem posleoperatsionnom periode u bolnykh s perelomami dlinnykh trubchatykh kostei [Prediction of pyoinflammatory complications in the early postoperative period in patients with fractures of long tubular bones]. Travmatologiia i Ortopediia Rossii, 2009, no. 4, pp. 88-90. (in Russian) 
12.Kochetkov A.V., Gudilov M.S. Kliniko-laboratornaia diagnostika i monitoring gnoino-septicheskikh oslozhnenii posle operatsii na organakh briushnoi polosti [Clinical and laboratory diagnostics and monitoring of purulent-septic complications after surgeries of the abdominal organs]. Novosti Khirurgii, 2015, vol. 23, no. 1, pp. 105-111. (in Russian) DOI: 1018484/2305-0047.2015.1.105

13.Horst K., Hildebrand F., Pfeifer R., Köppen K., Lichte P., Pape H.C., Dienstknecht T. Plate osteosynthesis versus hemiarthroplasty in proximal humerus fractures - does routine screening of systemic inflammatory biomarkers makes sense? Eur. J. Med. Res., 2015, vol. 20, no. 1, pp. 5. DOI: 10.1186/s40001-014-0079-Z

14.Gavrilova K.P., Fedorov V.E. Analiz prichin posleoperatsionnykh oslozhnenii v ekstrennoi khirurgicheskoi praktike: Tez. dokl. Konf. «Aspirantskie i doktorantskie chteniia: klinicheskie distsipliny» [Analysis of the causes of postoperative complications in emergency surgical practice: Proceedings of the Conference "Postgraduate and Doctoral Readings: clinical disciplines"]. Biulleten Meditsinskikh Internet-Konferentsii, 2013, vol. 3, no. 3, pp. 810. (in Russian)

15.Shchava S.P. Faktory rosta sosudov i neoangiogenez pri gipoksii i ishemii [Vascular growth factors and neoangiogenesis in hypoxia and ischemia]. Dalnevostochnyi Meditsinskii Zhurnal, 2007, no. 1, pp. 127-131. (in Russian)

16.Blanco R., Gerhardt H. VEGF and Notch in tip and stalk cell selection. Cold Spring Harb. Perspect. Med., 2013, vol. 3, no. 1, pp. a006569. DOI: 10.1101/cshperspect.a006569

17.Aiello L.P., Pierce E.A., Foley E.D., Takagi H., Chen H., Riddle L., Ferrara N., King G.L., Smith L.E. Suppression of retinal neovascularization in vivo by inhibition of vascular endothelial growth factor (VEGF) using soluble VEGF-receptor chimeric proteins. Proc. Natl. Acad. Sci. U S A, 1995, vol. 92, no. 23, pp. 10457-10461. DOI: 10.1073/pnas.92.23.10457

18.Ivanov A.N., Grechikhin A.A., Norkin I.A., Puchinian D.M. Metody diagnostiki endotelialnoi disfunktsii [Methods of diagnosing endothelial dysfunction]. Regionarnoe Krovoobrashchenie i Mikrotsirkuliatsiia, 2014, vol. 13, no. 4, pp. 4-11. (in Russian)

19.Liu T.L., Miao J.C., Sheng W.H., Xie Y.F., Huang Q., Shan Y.B., Yang J.C. Cytocompatibility of regenerated silk fibroin film: a medical biomaterial applicable to wound healing. J. Zhejiang Univ. Sci. B, 2010, vol. 11, no. 1, pp. 10-16. DOI: 10.1631/jzus. B0900163

Received: 20.02.2019

\section{Information about the authors:}

1. Anastasia A. Rakhmatulina,

Ilizarov National Medical Research Centre for Traumatology and Orthopedics, Kurgan, Russian Federation, Email: anastasiya_andreeva@mail.ru

2. Svetlana N. Luneva, Ph.D. of Biological Sciences, Professor, Ilizarov National Medical Research Centre for Traumatology and Orthopedics, Kurgan, Russian Federation, Email: luneva_s@mail.ru

3. Natalia V. Nak̄oskina,

Ilizarov National Medical Research Centre for Traumatology and Orthopedics, Kurgan, Russian Federation

4. Nikolai M. Kliushin, M.D., Ph.D.,

Ilizarov National Medical Research Centre for Traumatology and Orthopedics, Kurgan, Russian Federation, Email: klyushin_nikolay@mail.ru

5. Sergei V. Lyulin, M.D., Ph.D.,

Ural State Medical University, Ekaterinburg, Russian Federation,

Central City Clinical Hospital № 23, Ekaterinburg, Russian Federation

6. Tamara I. Dolganova, M.D., Ph.D.,

Ilizarov National Medical Research Centre for Traumatology and Orthopedics, Kurgan, Russian Federation, Email: rjik532007@rambler.ru

7. Tatyana I. Menshchikova, Ph.D. of Biological Sciences,

Ilizarov National Medical Research Centre for Traumatology and Orthopedics, Kurgan, Russian Federation, Email: tat-mench@mail.ru

8. Darya S. Leonchuk, M.D.,

Ilizarov National Medical Research Centre for Traumatology and Orthopedics, Kurgan, Russian Federation, Email: darya.leonchuk@mail.ru 